\title{
Małżeństwo w językowym obrazie świata. Na przykładzie paremii w języku polskim, rosyjskim i angielskim
}

\author{
Marriage in the linguistic view of the world. \\ On the example of Polish, Russian and English proverbs
}

\begin{abstract}
The essence of marriage is being widely discussed in the last few decades in many social circles and at many different levels. From the linguistic point of view it is usually characterised on the basis of man's and woman's roles in their relationship. The aim of the paper is to present the view of marriage in Polish, Russian and English proverbial phrases. For the purposes of the article about 350 Polish and Russian and about 300 English proverbs have been subjected to cognitive analysis. The research proves that the concept of marriage is roughly universal in all three languages and it presents definitely an androcentric perspective. Wives in proverbs are shown in a very unfavourable light as grouchy, quarrelsome, unfaithful and narrow-minded human beings. Marriage reflected in sayings is usually a burden which diminishes man's happiness and may even lead to his sickness, fast aging and death. What is more, quite a lot of proverbial phrases in all three languages under study foster violence against women. The concept of marriage presented in proverbs is undoubtedly a reflection of the old way of thinking and the old system of values, but the preliminary research of anti-proverbs, i.e. more modern expressions, proves that it has not undergone any fundamental changes in the language awareness of the Polish, Russian and English native speakers.
\end{abstract}

Keywords: marriage, wife, husband, proverbs, anti-proverbs

Katarzyna Kuligowska, Uniwersytet im. Adama Mickiewicza w Poznaniu, Poznań - Polska, katarzyna.kuligowska@amu.edu.pl, ORCID ID: https://orcid.org/0000-0001-8443-4815

Istota małżeństwa w ostatnich dekadach jest szeroko dyskutowana w wielu kręgach społecznych i na wielu poziomach. Dokonujące się zmiany światopoglądowe, demokratyzacja obyczajów oraz kryzys tradycyjnego modelu życia bez wątpienia mają znaczący wpływ na ton tych dyskusji. Jak wszelkie dokonujące się w społeczeństwach przemiany, tak i te, które dotyczą rodziny i małżeństwa, pozostawiają ślad w systemie języka. Językowy obraz małżeństwa jest tworem złożonym i wielostronnym, na który składa się m.in. warstwa wyłaniająca się 
z paremiologicznego zasobu języka oraz często pozostające w opozycji do niej niuanse zawarte we współczesnej publicystyce i stereotypy uwidaczniające się w swobodnych skojarzeniach, a także zwrotach metaforycznych. Szerokie badania dotyczące ról płci, stereotypów związanych z płcią, funkcjonowaniem przedstawicieli obu płci w społeczeństwie są prowadzone od co najmniej kilku dekad w różnych obszarach nauki (zob. m.in. Dąbrowska et al.). Na gruncie językoznawstwa są one zwykle skoncentrowane na przedstawieniu tzw. genderowego językowego obrazu świata opartego na charakterystyce społecznych funkcji kobiety i mężczyzny oraz wizji rodziny (zob. m.in. Bielińska-Gardziel et al.).

Celem niniejszego tekstu jest przedstawienie obrazu małżeństwa w paremiologii języka polskiego, rosyjskiego i angielskiego, w której uświęcony lub prawnie usankcjonowany związek mężczyzny i kobiety jest bogato reprezentowany. Na potrzeby artykułu analizie kognitywnej poddanych zostało po ok. 350 przysłów polskich i rosyjskich oraz ok. 300 przysłów angielskich w barwny sposób opisujących życie małżeńskie z jego blaskami i cieniami, zawierających zalecenia dla osób rozważających wstąpienie w związek małżeński, a także charakteryzujących członków tej wspólnoty, tj. męża i żonę, ich wady, zalety, zadania i oczekiwania ${ }^{1}$.

Za główny wątek w przysłowiach o tematyce małżeńskiej można uznać próbę oceny samej istoty małżeństwa i zasadności jego zawierania. W powiedzeniach wszystkich trzech języków zawarta jest zarówno pochwała małżeństwa i uznanie jego wyższości nad stanem kawalerskim lub panieńskim, jak i opinia o małżeństwie jako niewoli i źródle licznych kłopotów i trosk. Życie we dwoje jest, zgodnie $\mathrm{z}$ mądrością ludową, wpisane $\mathrm{w}$ naturę człowieka, nawet jeśli jest to życie $\mathrm{z}$ osobą daleką od ideału:

Ptak w klatce, ryba w sadzawce, człowiek bez żony mają świat zmierzwiony.

Za płotem to cieplej, za byle chłopem to lepiej.

Żeby chłop był jak wrona, zawsze żonie obrona.

Что гусь без воды, то мужик без жены.

Жена без мужа - всего хуже.

Одному и топиться идти скучно.

Where there is no wife, there is no home.

A woman without a husband, a house without foundation.

A man without a wife is but half a man.

Znamienne jest jednak to, że przysłowia ukazujące zalety i wartość stanu małżeńskiego tworzą mniej liczną grupę niż te, w których zawarta jest negatywna ocena małżeństwa:

1 Źródła wyekscerpowanych przysłów są wskazane w bibliografii. 
Wesela godzina, smutku całe życie.

Małżeństwo - męczeństwo.

Ciężki kamień młyński, jeszcze cięższy stan małżeński.

Kto się żeni, dobrze czyni, a kto się nie żeni, lepiej.

Женишься раз, а плачешься век.

Согрешил я перед господом, что люди меня оженили.

Холостой много думает, а женатый больше того.

Такого уж дело (женитьба), что всякому надоело.

Death and marriage make term day.

Honest men marry soon, wise not at all.

Marriage is a quick solution to more problems.

Matrimony is not a word but a sentence.

Warto podkreślić, że zarówno w przysłowiach polskich i rosyjskich, jak i angielskich wyrażone jest przekonanie o nieuchronności losu przy wyborze współmałżonka:

Mąż i żona od Boga przeznaczona.

Małżeństwa kojarzą się w niebie.

Суженого ни обойти, ни объехать.

Всякая невеста для своего жениха родится.

Marriage and hanging go by destiny.

Every Jack has his Jill.

Harmonijne życie w małżeństwie, które może zapewnić właściwy partner, przedstawiane jest w paremiach jako najwyższa wartość. Nieudane małżeństwo natomiast czyni życie trudnym do zniesienia. W obu przypadkach sentencje ludowe niemal bez wyjątku egzemplifikują męski punkt widzenia i obrazują jakość życia mężczyzny z dobrą lub złą żoną:

Dobra żona, perła droga, dana od samego Boga.

Dobra żona to wielkie błogosławieństwo, zła żona to wielkie przekleństwo.

Gdzie zła żona, tam piekło w domu.

Lepiej z lwem w puszczy niż ze złą żoną.

С доброй женой горе - полгоря, а радость вдвойне.

Добрая жена да жирные щи - другого добра не ищи!

От пожара, от потопа и от злой жены, боже, сохрани!

Лучше хлеб есть с водою, чем жить со злою женою.

A virtuous woman is a source of honour to her husband, a vicious one causes him disgrace.

A good wife's is a godly prize.

All are good lasses, but whence come the bad wives.

Better be half hanged than ill-wed. 
W opozycji do powiedzeń o ingerencji siły wyższej w wybór małżonka znajdują się liczne przysłowia zawierające przestrogi i rady dotyczące ożenku i zamążpójścia, co zdaje się świadczyć jednak o wierze części społeczeństwa w możliwość decydowania o własnym losie i jakości życia małżeńskiego.

Mądrość ludowa zaleca przede wszystkim rozwagę i rozsądek przed ślubem, zgodnie z tradycją bowiem decyzja o wstąpieniu w związek małżeński łączy dwoje ludzi na całe życie:

Żona nie gęśle, pograwszy, nie powiesisz na ścianie.

Ni to sprzedać, ni wymienić, lepiej było się nie żenić.

Муж не сапог, не скидается с ног.

Жениться - не воды напиться.

When weasel and cat make marriage, evil presage.

Hasty marriage seldom proveth ${ }^{2}$ well.

W świetle nierozerwalności małżeństwa śmierć współmałżonka w nieszczęśliwym związku bywa wybawieniem, a żałoba po zmarłej osobie jest bardzo krótkotrwała:

Póty mąż żony żałuje, póki się woda w garnku nie zagotuje.

Póty mężowska żałoba, póty nie wstawią żony do groba.

Tak to bolesne, komu żona umrze, jako kiedy kto zabije się w łokieć.

Дважды жена мила бывает: как в избу введут да как вон понесут.

Вдовец по тепленькой плачет жене, а как остыла и память отбило.

- Иван, жена умерла! - Одной сатаной меньше!

He that loses his wife and a farthing, has a great loss of his farthing.

Two good days for a man in his life: when he weds, and when he buries his wife.

When the wife dies and the mare foals, prosperity begins.

Niekiedy jednak nawet duża ostrożność i dalekowzroczność kandydatów do małżeństwa nie jest $\mathrm{w}$ stanie uchronić ich przed popełnieniem błędu życiowego, jak pokazują bowiem ludowe porzekadła, charakter i zachowanie małżonków po ślubie może ulec zmianie:

W koniu wiosna, w pannie ślub wady odkrywa.

Девка красна до замужества.

All are good lasses, but whence come the bad wives?

${ }^{2}$ Archaiczna forma 3 osoby liczby pojedynczej czasownika prove. 
Przy doborze partnera życiowego istotne jest przyjęcie właściwych kryteriów. Nie należy przywiązywać zbytniej wagi do wyglądu zewnętrznego współmałżonka, gdyż nie decyduje on o małżeńskim szczęściu, a nadmierna uroda może być jedynie źródłem wielu domowych kłopotów, a nawet zdrady małżeńskiej:

Na gładką żonę patrząc, syty nie będziesz.

Ładna żona jak groch przy drodze.

Żona ładna, zawsze zdradna.

С лица воду не пить, можно и с рябою жить.

Глупому мужу красная жена дороже красного яйца.

Не ищи в муже красоты, а ищи доброты.

He who has a fair wife needs more than two eyes.

The uglier the man, the better the husband.

If you marry a beautiful blonde, you marry trouble.

Sprzeczne opinie pojawiają się w przysłowiach dotyczących zamożności przyszłej małżonki lub przyszłego męża. Część paremii zdecydowanie odradza kierowanie się względami materialnymi przy doborze partnera życiowego, podczas gdy inne kwestiom finansowym przypisują istotne znaczenie. Duży posag decyduje o wartości i statusie kobiety w przyszłym małżeństwie, a ponadto może dawać jej władzę nad mężem, jeśli jego majątek jest mniej pokaźny.

Lepiej wziąć skarb w żonie niż za żoną.

Choćby była jako gwiazda, bez posagu na nic każda.

Gdy się żenisz z równą, bierzesz żonę; gdy z bogatą, zyskujesz panią.

Не с богатством жить, с человеком.

Лучше на убогой жениться, чем с богатой браниться.

Богатую взять, станет попрекать.

Better a fortune in wife than with a wife.

Never marry for money, but marry where money is.

He that marries for wealth, sells his liberty.

W wielu analizowanych porzekadłach eksplikowane są zalecenia (często sprzeczne) dotyczące wieku kandydatów do małżeństwa, a także ostrzeżenia i uwagi odnoszące się do par, które dzieli zbyt duża różnica wieku:

Kto się zbyt młodo żeni, ten wolności nie ceni.

W późnym wieku diabeł swatem.

Późne małżeństwo - wczesne sieroty.

Z młodym stara - śmieszna para, stary z młodą grozi szkodą.

Jako ogień bywa z wodą, tak i stary z żoną młodą. 
Невеста родится, а жених на конь садится.

У старого мужа молодая жена - чужая корысть.

Ненадолго старый женится.

Старый конь - на убой, старый муж - на смех.

По старому мужу молодая жена не тужит.

A young man married is a young man marred.

It is good to marry late or never.

Early marriage, long love.

He that marries late, marries ill.

Young man should not marry yet, an old man not at all.

Obraz małżeństwa w warstwie paremiologicznej konstruowany jest także poprzez eksplikację wad i pochwałę zalet współmałżonków, choć należy podkreślić, iż oceną charakterologiczną objęte są przede wszystkim kobiety. Do najbardziej cenionych i poszukiwanych atrybutów żony należy małomówność, cnotliwość, gospodarność i delikatność:

Jak drzwi, które nie skrzypią, tak żona, która milczy, najprzyjemniejsza.

Cnotliwa żona męża korona.

С лица воду не пить, умела бы пироги печь.

Красна пава пером, а жена нравом.

In the husband wisdom, in the wife gentleness.

A quiet wife is mighty pretty.

Jako główne ułomności żon wskazywane są takie cechy charakteru, jak gadatliwość, zrzędliwość, kłótliwość, przyziemność, rozrzutność i niewierność:

Mąż żony nigdy nie przegada.

Żona rzadko bez gnomona.

Сварливая жена - в доме пожар.

Муж в шанцах, а жена в танцах.

Maids want nothing but husbands, and when they have them, they want everything.

A faithless wife is a shipwreck of the home.

Małżeństwo to jednak taki typ relacji, w którym obie strony mają na siebie wpływ i decydują o jego powodzeniu:

U dobrego męża dobra żona.

U dobrego męża żoneczka jak róża, a u złego draba we trzy lata baba.

У плохой бабы муж на печи лежит, а хорошая сгонит.

Доброю женою и муж честен. 
A good wife makes a good husband.

Choose a horse made and a wife to make.

Warunki konieczne do stworzenia dobrze funkcjonującego i harmonijnego związku małżeńskiego to kompromis, dążenie do zgody, wzajemny szacunek oraz brak ingerencji osób trzecich:

Dobrze czasem, gdy mąż głuchy, a żona ślepa.

Dobre małżeństwo, gdzie rozjemcy nie ma.

Почитай отца и мать, а жену - впятеро.

Промеж мужа и жены нитки не продернешь.

A deaf husband and a blind wife are always a happy couple.

Marriage is a game best played by two winners.

Przysłowia wspominają także o koniecznym umiarkowaniu w szczerości małżonków względem siebie:

Chłopa nie cyganić, ale mu prawdy nie mówić.

Chcesz li mieć co tajemnego, nie zwierzaj się żonie z tego.

Не всякую жена мужу правду сказывает.

И дура-жена мужу правды не скажет.

The husband is always the last to know.

He that tells his wife news is but newly married.

Czynnikiem, który zdecydowanie negatywnie wpływa na funkcjonowanie małżeństwa, jest zdrada. Przysłowia przestrzegają, iż małżonek dopuszczający się zdrady prędzej czy później sam też doświadczy nielojalności i niedoli:

Zdrada na autora zawsze spada.

Тот сам себя губит, кто чужую жену любит.

Each husband gets the infidelity he deserves.

Symptomatyczne jest, że cudzołóstwo popełnione przez żonę ma w przysłowiach rosyjskich i angielskich znacznie większy ciężar gatunkowy, podczas gdy waga grzechu niewierności męża jest umniejszana i bagatelizowana:

Муж задурит, половина двора горит; а жена задурит, и весь горит.

Муж согрешил, так в людях грех, а жена согрешила, домой принесла.

A faithless wife is the shipwreck of the home.

If a man is unfaithful to his wife, it's like spitting from a house into a street, but if a woman is unfaithful to her husband, it's like spitting from the street into the house. 
W świetle mądrości ludowej małżonkowie powinni dobrze znać swoje role, każde $\mathrm{z}$ nich bowiem pełni w związku określone funkcje. Zadaniem żony jest przede wszystkim dbałość o ognisko domowe oraz uległość wobec mężczyzny, podczas gdy mąż stworzony jest do pełnienia funkcji kierowniczej. Wszelkie zmiany w tym zakresie stanowią zagrożenie dla właściwego funkcjonowania rodziny:

Źle, gdy kura siada wyżej niż kogut.

Biada temu domowi, gdzie żona przewodzi mężowi.

Niedobrze tam, gdzie mąż w spódnicy, a żona w spodniach chodzi.

Не муж в мужьях, кем жена владеет.

Вот худо, как муж дьякон, а жена попадья.

Жена мужу пластырь, а муж жене пастырь.

When a man is a fool, his wife will rule.

Among those whose life is not life is the man who is ruled by his wife.

When the wife rules the house, the devil is man-servant.

Zdarzają się jednak i takie pary małżeńskie, w których władza męża jest tylko pozorna, natomiast rzeczywistą kontrolę dzięki swojemu sprytowi i inteligencji pełni żona, często utrzymując męża w przekonaniu, że jest odwrotnie:

Kędy sam głupi, a zaś mądra ona - tam niech mąż żoną, mężem będzie żona.

Mąż doradza, a przy żonie władza.

Исподний жернов перемалывает верхний.

Жена мужа не бьет, а под свой нрав ведет.

An obedient wife commands her husband.

A woman can't drive her husband, but she can lead him.

Prezentowana w przysłowiach męska dominacja w związkach małżeńskich nie ogranicza się jedynie do decyzyjnej roli mężczyzny. W patriarchalnym modelu małżeństwa zobrazowanym $\mathrm{w}$ analizowanych powiedzeniach akceptowana, bagatelizowana, a nawet zalecana jest przemoc wobec żony. Agresywne zachowanie mężczyzny ma warunkować właściwe podejście małżonki do obowiązków rodzinnych i jest jakoby potwierdzeniem miłości męża:

Żona, jak mięta, im mocniej się ją mnie, tym więcej pachnie.

Kochaj żonę całą duszą, a trząś nią jak gruszą.

Kiedy mąż do dziewiątej skóry dobija, wtedy dobra żona.

Mąż żony nie miłuje, kiedy skóry nie wecuje.

Бей жену обухом, припади да понюхай: дышит да морочит, еще хочет.

Всем бита, и об печь бита, только печью не бита. 
Люби жену, как душу, тряси ее, как грушу.

Шубу бей - теплее, жену бей - милее.

A wife and walnut tree, the more you beat them, the better they be.

Women, like gongs, should be beaten regularly.

Good horses and bad horses need the spurs, good women and old women need the whip.

Love well, whip well.

Podsumowując, należy podkreślić, że badania nie wykazały znaczących różnic pomiędzy językiem polskim, rosyjskim i angielskim, co świadczy o uniwersalności zagadnień, problemów i aspektów życia małżeńskiego. Małżeństwo zobrazowane w poddanych analizie ludowych sentencjach to rzeczywistość zdecydowanie androcentryczna. Męski punkt widzenia prezentuje ok. $67 \%$ polskich, ok. $64 \%$ rosyjskich i ok. $60 \%$ angielskich przysłów stanowiących materiał empiryczny. Badacze mówią nawet o skumulowanym mizoginizmie (Yusuf, źródło elektroniczne), seksizmie i antyfeminizmie w przysłowiach różnych narodów, bez względu na kulturę (Litovkina 4; Zheng, źródło elektroniczne). Mężczyźni są przedstawieni jako skazani na mało skuteczne poszukiwania idealnych żon. Te poślubione zaś w codziennym życiu okazują się zrzędliwe, kłótliwe, gadatliwe i skłonne do zdrad. Kobiety ukazywane są jako istoty o mniejszym potencjale intelektualnym, zatem konieczna jest dominacja męża w związku małżeńskim, która nierzadko polega na uciekaniu się do przemocy domowej (Schipper, źródło elektroniczne).

Podobnie negatywny obraz małżeństwa oraz kobiety w roli żony jako istoty próżnej, kłótliwej, niewiernej i mało inteligentnej zawarty jest w tzw. antyprzysłowiach, czyli żartobliwych transformacjach kanonicznych przysłów. Taki stan rzeczy potwierdzają badania Anny Litovkiny nad angielskimi przekształceniami paremicznymi (Litovkina), analiza materiału leksykalnego zawartego w słowniku antyprzysłów rosyjskich (Val'ter, Mokienko), jak również opracowania z zakresu przekształceń przysłów polskich (Kozioł-Chrzanowska), por.:

Gość w dom, żona w ciąży.

Żona nie zając, nie ucieknie.

Kawaler - to paw, zaręczony - lew, a żonaty - osioł.

Брак - это основная причина разводов.

Если ты хочешь, чтобы жена тебе не изменяла, не женись.

Если вы хотите жениться на умной, красивой и богатой, вам придется жениться три раза.

Marriages are made in heaven... So is thunder and lightning.

Love is blind, and marriage is an eye-doctor.

Matrimony is the root of all evil.

Podrzędny status kobiety jest niewątpliwie uniwersalnym faktem kulturowym (Karwatowska 278). Językoznawcy opisujący zakorzeniony w języku obraz ko- 
biety jako istoty podległej mężczyźnie zgodnie upatrują źródeł tego stanu rzeczy w kanonach chrześcijaństwa. Zarówno więc starotestamentowy opis stworzenia kobiety z żebra mężczyzny, jak i nowotestamentowy nakaz uległości wobec męża na zawsze zdeterminowały jej społeczny status. Dodatkowo przypisana kobiecie odpowiedzialność za grzech pierworodny przyczyniła się do postrzegania jej jako źródła wszelkiego zła i niemoralności (Tamerjan 46-47, Gasanova et al., źródło elektroniczne).

Małżeństwo w warstwie paremiologicznej badanych języków jest w większości oceniane negatywnie i jest to ocena z punktu widzenia mężczyzny. Nieliczne tylko porzekadła mówią o dobrej żonie i szczęśliwym mężu. Wizerunek związku małżeńskiego zawarty $\mathrm{w}$ paremiach to niewątpliwie odzwierciedlenie dawnego sposobu myślenia i systemu wartości, jednak wstępna analiza antyprzysłów, czyli wyrażeń bliższych współczesnemu człowiekowi, zwykle podważających prawdę wyrażaną przez porzekadła, pokazuje, że nie zmienił się on zasadniczo w świadomości językowej użytkowników języka polskiego, rosyjskiego i angielskiego. Obraz małżeństwa w żartobliwych transformacjach powiedzeń oraz współczesnym dyskursie publicznym wymaga poszerzonych badań, które pozwolą na jego szczegółowy i pełny opis.

\section{Bibliografia}

Bielińska-Gardziel, Iwona. Stereotyp rodziny we wspótczesnej polszczyźnie. Warszawa, Slawistyczny Ośrodek Wydawniczy, 2009.

Dąbrowska, Zofia. „Małżeństwa w Polsce współczesnej. Studium empiryczne”. Roczniki Socjologii Rodziny, t. 13, 2001, s. 29-43.

Gasanova, Marina, Patimat Magomedova, Salminat Gasanova. „Linguoculturological Analysis of Woman's Image in the Proverbs and Sayings of the Dagestan Languages". International Journal of Environmental \& Science Education, vol. 11, 18, 2016, s. 11869-11887. Web. 25.06.2019. https://files.eric.ed.gov/fulltext/EJ1121769.pdf.

Hovhannisyan, Lilit. Gender Relations in English and Armenian Proverbs. Yerevan 2017. Web. 12.07.2019. https://baec.aua.am/files/2017/09/Lilit_Hovhannisyan_Gender-Relations-in-English-and-Armenian Proverbs_Capstone.pdf.

Jagielska, Anna. „Orzech, osioł i niewiasta, czyli stereotypy płci w przysłowiach”. Niebieska Linia, 5, 2004. Web. 27.06.2019. https://www.niebieskalinia.pl/pismo/wydania/dostepne-artykuly/ 4484-orzech-osiol-i-niewiasta-czyli-stereotypy-plci-w-przyslowiach.

Jarosz, Beata. Językowy obraz ślubu. Lublin, Wydawnictwo Uniwersytetu Marii Curie-Skłodowskiej, 2014.

Karwatowska, Małgorzata. „Uległa, podporządkowana i piękna, czyli stereotyp kobiety dawniej i dziś”. Dialog kultur w edukacji. Red. Barbara Myrdzik, Małgorzata Karwatowska. Lublin, Wydawnictwo Uniwersytetu Marii Curie-Skłodowskiej, 2009, s. 270-278.

Kerschen, Lois. American Proverbs about Women: A Reference Guide. Westport, Connecticut, London, Greenwood Press, 1998. 
Kirsanova, Maria. „Androcentrism of English Proverbs and Anti-Proverbs with Gender Components". Journal of Language and Education, 4 (2), 2018, s. 68-77. Web. 12.07.2019. https:// doi.org/10.17323/2411-7390-2018-4-2-68-77.

Kocik, Lucjan. Rodzina w obliczu wartości i wzorów życia ponowoczesnego świata. Kraków, Krakowskie Towarzystwo Edukacyjne, 2006.

Kozioł-Chrzanowska, Ewa. „Przekrojowa” rubryka „Heca heca” jako źródło potocznych reproduktów języka polskiego. Kraków, Wydawnictwo Libron, 2015. Web. 14.07.2019. http://rcin. org.pl/Content/63424/Heca\%20hecą\%20-\%20ostateczny\%20pdf.pdf.

Litovkina, Anna T. Women Through Anti-Proverbs. Cham, Palgrave Macmillian, 2019.

Monger, Georg P. Marriage Customs of the World: An Encyclopaedia of Dating Customs and Wedding Traditions. Santa Barbara, Denver, Oxford, ABC-CLIO, 2013.

Ničiporčik, Elena Vladimirovna. „Aksiologičeskij portret ženŝiny v ital'ânskih i russkih paremiâh (v poiskah sub"ekta ocenki)". Problemy istorii, filologii, kul'tury, 4 (26), 2009, s. 181-195. Web. 28.05.2019. https://cyberleninka.ru/article/v/aksiologicheskiy-portret-zhenschiny-v-italyanskih-i-russkih-paremiyah-v-poiskah-subekta-otsenki.

Rodziewicz, Barbara. „Póty mąż żonę całuje, póki się kapusta na ławce gotuje. Mężczyzna - mąż i głowa rodziny we frazeologii polskiej i rosyjskiej”. Z zagadnień semantyki i stylistyki tekstu. Red. Anna Ginter. Łódź, Wydawnictwo Uniwersytetu Łódzkiego, 2010, s. 245-249.

Schipper, Mineke. „A Thousand Proverbs Later, It’s Still a Brutality”. Los Angeles Times, 20.04.2004. Web. 14.08.2019. https://www.latimes.com/archives/la-xpm-2004-apr-20-oe-schipper20-story.html. Skoczylas-Krotla, Edyta. „Obraz rodziny w przysłowiach różnych narodów”. Prace Naukowe Akademii im. Jana Dlugosza w Częstochowie. Seria: Językoznawstwo, 7, 2010, s. 155-163.

Szulich-Kałuża, Justyna. Mał̇eństwo i rodzina w polskiej prasie. Lublin, Wydawnictwo KUL, 2010.

Tamer'ân, Tat'âna Ûl'evna. „Aksiologičeskij status anglijskoj gendernoj kartiny mira (na materiale paremiologii)". Vestnik RUDN. Seriâ Teoriâ âzyka. Semiotika, 13, 2014, s. 46-53. Web. 28.05.2019. https://cyberleninka.ru/article/n/aksiologicheskiy-status-angliyskoy-gendernoy-kartiny-mira-na-materiale-paremiologii.

Yusuf, Yisa Kehinde. „The Sexist Correlation of Women with the Non-Human in English and Yoruba Proverbs". De Proverbio, vol. 3, 1, 1997. Web. 15.08.2019. https://deproverbio.com/the-sexist-correlation-of-women-with-the-non-human-in-english-and-yoruba-proverbs/.

Zheng, Xin. „The Analysis of Sexism in English Proverbs”. Journal of Language Teaching and Research, vol. 9, 2, s. 352-357. Web. 14.07.2019. http://www.academypublication.com/ojs/index. $\mathrm{php} / \mathrm{j}$ ltr/article/view/jltr0902352357.

\section{Słowniki}

Adalberg, Samuel. Stownik przysłów, przypowieści i wyrażeń przysłowiowych polskich. Web. 18.05.2019. http://bc.wbp.lublin.pl/dlibra/docmetadata?id=11434\&from=publication.

Cordry, Harold V. The Multicultural Dictionary of Proverbs: Over 20000 Adages from More Than 120 Languages, Nationalities and Ethnic Groups. London, Mc Farland \& Company, 2005.

Dal', Vladimir Ivanovič. Poslovicy russkogo naroda. Web. 20.05.2019. https://vdahl.ru.

Herman, Bernadeta, Jerzy Syjud, wyb. Księga przystów. Katowice, Videograf II, 1998.

Kłosińska, Katarzyna. Słownik przysłów: przysłownik. Poznań, Publicat, 2011.

Litovkina, Anna T., Wolfgang Mieder. Old Proverbs Never Die. They Just Diversify. A Collection of Anti-Proverbs. Veszprém, University of Veszprém Press, 2006.

Litovkina, Anna T., Wolfgang Mieder. Twisted Wisdom. Modern Anti-Proverbs. Vermont, University of Vermont, 1999. 
Masłowska, Danuta, Włodzimierz Masłowski, wyb. Przysłowia polskie. Katowice, Videograf II, 1997.

Mieder, Wolfgang, red. A Dictionary of American Proverbs. Oxford, Oxford University Press, 1992.

Schipper, Mineke. Never Marry a Woman with Big Feet. Women in Proverbs from Around the World. Amsterdam, Amsterdam University Press, 2006.

Simpson, John Andrew, Jennifer Speake, red. The Concise Oxford Dictionary of Proverbs. Oxford, Oxford University Press, 1992.

Smith, William George. The Oxford Dictionary of English Proverbs. Oxford, Clarendon Press, 1963.

Strauss, Emmanuel. Dictionary of European Proverbs. London-New York, Routledge, 1994.

Stypuła, Ryszard. Stownik przysłów rosyjsko-polski i polsko-rosyjski. Warszawa, Państwowe Wydawnictwo „Wiedza Powszechna”, 1974.

Świerczyńska, Dobrosława, wyb. Kobieta, miłość, małzeństwo. Przystowia różnych narodów. Warszawa, Książka i Wiedza, 1994.

Świrko, Stanisław, wyb. Na wszystko jest przystowie: popularny wybór przysłów polskich w układzie tematyczno-hasłowym. Poznań, Wydawnictwo Poznańskie, 1975.

Val'ter, Harri, Valerij Mihajlovič Mokienko. Antiposlovicy russkogo naroda. Sankt-Peterburg-Moskva, Izdatel'skij dom „Neva”, 2005. 